\title{
New Thinking on Capacity Cooperation between China and Africa under the "Belt and Road Initiative"
}

\author{
Yiding Li \\ Business School, China University of Political Science and Law, Beijing, China \\ Email: liyiding@eximbank.gov.cn
}

How to cite this paper: Li, Y.D. (2019) New Thinking on Capacity Cooperation between China and Africa under the "Belt and Road Initiative". Open Journal of Social Sciences, 7, 95-106. https://doi.org/10.4236/jss.2019.712008

Received: November 6, 2019

Accepted: December 3, 2019

Published: December 6, 2019

Copyright () 2019 by author(s) and Scientific Research Publishing Inc. This work is licensed under the Creative Commons Attribution International License (CC BY 4.0).

http://creativecommons.org/licenses/by/4.0/

Open Access

\begin{abstract}
International Capacity Cooperation China proposes a new model of international economic cooperation, which is of great significance for promoting China's surplus capacity transfer and industrial transformation and upgrading. It is an inevitable choice for China to respond to changes in the global industrial chain. This paper uses the "geese line model" theory to explore the opportunities and challenges of China-Africa international capacity development. The study finds that the scale of China-Africa capacity cooperation is expanding, and China's foreign implementation of the "flying geese model" drives the economic development of underdeveloped countries in Africa. The status quo of non-capacity cooperation: at present, the cooperation mode between other countries and Africa poses a challenge to China-Africa international capacity cooperation. China-Africa industrialization cooperation and other cooperation have not been coordinated, and Africa is hard to bear the large-scale capacity transfer in China in the short term. This is the challenge of capacity cooperation between China and Africa. Therefore, China-Africa capacity cooperation must consolidate the foundation of sustainable development of China-Africa relations, and at the same time strengthen infrastructure construction to help economic and trade development, and jointly improve the development of the service industry, build Chinese business cards, and enhance corporate brands. Looking into the future, China-Africa capacity cooperation model has two directions: first, to build industrial parks, to undertake labor-intensive industry transfer; second, African countries to upgrade infrastructure through China-Africa Industrial Park.
\end{abstract}

\section{Keywords}

“One Belt, One Road” Initiative, China-Africa Capacity Cooperation, Capacity Transfer, New Thinking 


\section{Introduction}

The "Belt and Road Initiative" initiative plans new ideas for China's opening up to the outside world, builds an important platform for expanding international exchanges, and forms an important mechanism for China's wider participation in global economic governance. Africa has historically been a natural extension of the "Maritime Silk Road" and is currently the most concentrated area of developing countries in the world. For a long time, China and Africa have maintained close political ties, economic and trade relations have developed rapidly, and coordination and cooperation in international affairs have been increasingly strengthened. With the continuous deepening of China-Africa capacity cooperation, the "One Belt, One Road" initiative will help China to develop its wilderness model, transfer production capacity, and promote the transformation and upgrading of Chinese enterprises. At the same time, China and Africa will make better use of their comparative advantages to create economic development. The complementary effects, the more comprehensive promotion of common development and the goal of achieving common prosperity have profound implications [1].

\section{Literature Review}

International capacity cooperation is a new model proposed by China in recent years. It has important guiding significance for promoting China's surplus capacity transfer and industrial transformation and upgrading, and is an inevitable choice for China to respond to changes in the global industrial chain [2]. Theories involving international capacity cooperation mainly include regional economic cooperation, international economic cooperation, international capacity cooperation, and the "Belt and Road Initiative" initiative. This paper tries to analyze the opportunities and challenges of China-Africa international capacity development with the theory of "God's Way".

\subsection{The Origin of the Geese Pattern}

In the early 1930s, the so-called "geese" economic development theory put forward by Kaname Akamatsu, a professor of economics at Hitotsubashi University in Tokyo, gained widespread support and reputation in the context of the rapid growth of East Asia's economy. In the early days, Japan took over international production capacity and integrated it into the world's production system, which enabled the Japanese economy to develop rapidly, followed by Hong Kong, China, Singapore, and Taiwan. China and the four ASEAN countries gradually joined the world in the late twentieth century, and the economy developed rapidly [3]. This theory is often mentioned in academic literature on economic development, international trade and foreign direct investment. The media also often uses the term "wild gossip model", especially to describe the growth model that developing countries follow the developed countries.

\subsection{Development of the Geese Mode}

Scholars at home and abroad have given the understanding and definition of the 
geese pattern through the development of the national economic development model. Some scholars believe that the geese mode is a "level-linked economy" concept brought about by the power of growth clusters dominated by hegemony. To develop in developing countries, it is necessary to establish close commercial ties with developed countries and advanced countries in the subregion. As a result, developing countries can use the purchasing power of developed countries and industrial technology to develop their economies. Developing countries have the ability to develop more rapidly than early developers within the established policy framework, mainly because developing countries can introduce mature expertise from abroad without having to develop new technologies and turn farmers into workers through exports. Oriented manufacturing to gain productivity, while export-oriented manufacturing uses imported technology to complete manufacturing in the country [4].

\subsection{Traps in Middle-Income Countries}

For the rapid growth of the economy, most scholars hold a pessimistic attitude. They believe that rapid economic growth means a rapid economic recession in the future. At the same time, it is considered that there is no long-term stable economic growth. increase. East Asian countries have seized the good opportunity of industrial transfer and achieved relatively stable economic growth in the past four decades, but they are skeptical about whether they can continue to maintain growth. Through historical data from 74 developed and developing countries between 1950 and 1990, most developed countries began to slow down in the 1970s; most developing countries, especially Latin American countries, experienced a recession in 20 the 80 s [5].

\subsection{Comparative Advantage Development Strategy}

Combined with China's development experience, domestic scholars mostly agree with the comparative advantage development strategy in the new structural economics. The new structural economics is linked to a country's resource endowments and comparative advantages through the "goose-line model", emphasizing that companies in one industry use the comparative advantages of developing countries in a perfectly competitive market economy to achieve acceptable expected profits [6]. It has played a "post-development advantage" to achieve a successful economic transformation. The optimal industrial structure of an economy depends on the richness of its resources, capital, and labor. For countries with different stages of development, the production factors required by different industries are different, and the overall factor endowment of a country determines the direction of the chosen industry. However, as the economy continues to grow, the comparative advantage will also change.

\subsection{The Focus of the Geese Pattern Debate}

Some scholars believe that the domestic geese mode can be realized, that is, to 
revitalize the northeast and transfer production capacity to the west. This is not feasible. The geese pattern is connected through layers. Different countries have different resource endowments, such as labor costs, natural resources, and core technologies. The domestic core technology is convenient to flow, and can not form a generation difference; personnel can flow freely, and the advantage of human resource endowment cannot be formed in one region. Natural resources are classified by the state and are difficult to be fully grasped by local governments [7]. Funds flow freely in the country, while foreign countries have relatively cumbersome regulations on the use of funds.

\section{The Status Quo of China-Africa Capacity Cooperation}

\subsection{China-Africa Capacity Cooperation Trend}

China-Africa trade was less in 2000-2002 and lacked bilateral economic and trade exchanges. In 2000, China-Africa trade totaled only US $\$ 10.59$ billion (source: Wande Database, same below). China's total exports from Africa were slightly more than exports, at US $\$ 5.55$ billion [8]. China-Africa trade accounts for only $3.8 \%$ of Africa's foreign trade, accounting for $2.2 \%$ of China's foreign trade, and Africa's exports are mainly raw materials and primary products. It can be seen that for China and Africa, the total trade volume between China and Africa is very small in the total foreign trade of both sides. From 2001 to 2002, the total trade volume between China and Africa reached 10.79 billion U.S. dollars and 12.38 billion U.S. dollars, up 14.7\% year-on-year. China's exports to Africa and imports from Africa reached $15.9 \%$ and $13.2 \%$ respectively, although the growth rate was faster. However, it is still lower than the growth rate of China's import and export [9].

During 2003 and 2013, China and African countries successively negotiated the Addis Ababa Action Plan (2004-2006), the China-Africa Cooperation Forum Beijing Summit Declaration and the China-Africa Cooperation Forum-Beijing Action The plan (2007-2009) and other important documents have promoted the official start of the explosive growth of China-Africa trade. In 2003, China-Africa trade totaled 18.54 billion U.S. dollars (source: Wande database, same below), an increase of $49.7 \%$ year-on-year [10]. Among them, China imported 8.36 billion U.S. dollars to Africa, an increase of $54 \%$, and China's exports to Africa were 10.18 billion U.S. dollars., an increase of $46 \%$, the growth rate is much higher than the annual growth rate of $16.7 \%$ of global trade; and higher than the growth rate of Africa's foreign exports and imports during the same period, it is also higher than China's foreign import and export growth rate during the same period. In 2004, the total trade volume between China and Africa reached US\$29.46 billion, a year-on-year increase of $58.9 \%$, the highest record since 2000, and China's import volume from Africa reached $87 \%$. It is also from 2004 that China-Africa trade turned into a deficit, and Africa's exports to China exceeded US\$1.83 billion. The growth rate of Sino-US trade between 2005 and 2008 reached $34.9 \%, 39.6 \%, 32.7 \%$ and $45.1 \%$, respectively, which was lower 
than the growth rate in 2004, but still maintained rapid growth [11]. In 2008, China-Africa trade totaled US $\$ 106.84$ billion, exceeding the US $\$ 100$ billion mark two years ahead of schedule. China-Africa trade accounted for $10.23 \%$ of Africa's foreign trade and $4.17 \%$ of China's foreign trade.

Due to the single and fragile economic structure of African countries, they were hit hard in the financial crisis of the second half of 2008. Their trade declined in 2009, but China still decided to continue to open up the African market, reduce debts and increase investment. Practically help Africa to restore its economy. At the same time, the development of China and Africa has gradually changed from a single mode of cooperation with goods to a diversified economic and trade cooperation focusing on technology, project contracting, investment and services. From 2010 to 2012, China-Africa trade volume increased by $39.4 \%$, $30.9 \%$ and $19.3 \%$, and China's imports from Africa increased more than China's export growth to Africa, resulting in a large trade deficit, 2012 The trade deficit between China and Africa has reached a maximum of US $\$ 27.85$ billion to date.

Before 2014, China-Africa trade achieved rapid growth for many years and reached an all-time high of US\$221.94 billion in 2014. However, in the following two years, due to the fluctuation of international commodity prices, the volume of trade between China and Africa has dropped significantly. The total volume of imports and exports fell to 148.96 billion U.S. dollars in 2016, a decrease of $32.9 \%$ from 2014. In 2017, under the background of the stabilization of commodity prices and the recovery of the world economy, the bilateral trade volume between China and Africa has rebounded.

\subsection{Scale of China-Africa Cooperation}

According to Wande statistics, the total import and export volume of China and Africa in 2017 was about 169.75 billion US dollars, up 13.83\% from 2016's 149.12 billion US dollars, exceeding the overall growth of foreign trade in China during the same period. The total import and export volume of China's top ten trading partners in Africa is 116.448 billion US dollars, accounting for $68.5 \%$ of the total import and export volume between China and Africa. Among them, China's exports to Africa were 94.74 billion US dollars, up 2.7\% from 2016's 92.22 billion US dollars, and imports from Africa were 75.26 billion US dollars, up 22.5\% from 2016's 56.9 billion US dollars.

As of October 2018, China's top ten trading partners in Africa were South Africa, Angola, Nigeria, Egypt, Algeria, Congo, Congo, Ghana, Libya and Kenya.

As can be seen from Table 1, in the first 10 months of 2018, China imported four countries with more than 10 billion yuan from Africa. In 2016, only South Africa and Angola imported more than 10 billion US dollars. Although Africa's total import and export volume to China is generally balanced, from a single country perspective, some African countries have more exports and fewer imports, while some African countries have the opposite. Most of China's African countries importing from Africa are African resource-based countries, such 
Table 1. The chart shows China's top ten countries in terms of total imports and exports to Africa.

\begin{tabular}{cccc}
\hline African places & Total import and export & Total imports & Total export \\
\hline $\begin{array}{c}\text { Unit: } 100 \text { million US } \\
\text { dollars }\end{array}$ & $\begin{array}{c}\text { Unit: } 100 \text { million US } \\
\text { dollars }\end{array}$ & $\begin{array}{c}\text { Unit: } 100 \text { million US } \\
\text { dollars }\end{array}$ & $\begin{array}{c}\text { Unit: } 100 \text { million US } \\
\text { dollars }\end{array}$ \\
\hline South Africa & 369.41 & 232.81 & 136.6 \\
Angola & 231.68 & 213.3 & 18.38 \\
Nigeria & 120.68 & 12.54 & 108.14 \\
Egypt & 112.59 & 14.71 & 97.88 \\
Algeria & 75.72 & 8.99 & 66.73 \\
Congo Gold & 63.21 & 48.59 & 14.62 \\
Congo & 59.22 & 55.62 & 3.6 \\
Ghana & 57.67 & 18.65 & 39.02 \\
Libya & 47.1 & 35.37 & 11.73 \\
Kenya & 44.44 & 1.5 & 42.94 \\
\hline
\end{tabular}

as South Africa, one of Africa's five major mineral countries, Africa's "three major oils", Angola, Nigeria and Libya, and African copper majors, Congo and Congo. In the table, the countries that import less energy minerals import relatively more products, mainly in recent years, African countries promote opening to the outside world, and vigorously introduce foreign capital to accelerate the construction of infrastructure, such as industrial parks, power stations, roads and railways. Among them, Chinese-funded enterprises occupy a dominant position. The construction and construction in Africa have driven the export of China's electromechanical products. The import components of countries with more African imports are mainly engineering contracting, mechanical and electrical products and agricultural products.

Overall, China's international capacity cooperation with Africa is on the way to a new level. In the past, African resource countries exported raw materials such as minerals, and China exported finished products to Africa. Now Africa is gradually building its own manufacturing industry. China exports mechanical and electrical equipment to Africa. While Africa continues to export mineral resources to China, it is also gradually exporting some light industrial products and low-end mechanical and electrical products.

\subsection{Characteristics of China-Africa International Capacity Cooperation}

After 40 years of reform and opening up, China's economic development has entered a new stage, and the corresponding high-tech industries and infrastructure have entered a new ladder with the changes in industrial structure. From the perspective of new structural economics, the role of the government is to formulate new development strategies that are in line with comparative advan- 
tages, to ensure the smooth upgrading of internal industries, and to gradually shift the industries that have lost competitiveness. In the past, China's economic development relied mainly on the advantages of human capital. By introducing foreign capital and technology, labor-intensive industries were established. With the gradual increase of labor costs, the profits of labor-intensive industries are gradually shrinking. From the perspective of China, labor-intensive industries and industries with comparative advantages in urban areas need to be transferred overseas.

Under the "Belt and Road Initiative" initiative, China's internal optimization of resource allocation will gradually develop into capital-intensive and technology-intensive industries upstream of the industrial value chain to achieve sustainable economic growth. China's foreign implementation of the "flying geese model" has driven the economic development of less developed countries. Africa has a large number of human capital advantages. On the one hand, it can undertake the profession of China's labor-intensive industries, on the other hand, it can upgrade the manufacturing level of the country and accelerate the process of industrialization.

\section{China-Africa International Capacity Cooperation Model}

\subsection{The Cooperation Model between Other Countries and Africa Poses a Challenge to China-Africa International Capacity Cooperation}

The turning point of China-Africa international capacity cooperation model was during the 2006 China-Africa Summit. China-Africa relations did not attract the attention of the international community before the 2006 summit. At that time, China-Africa relations were still at a stage of restorative development. The United States and Europe were busy with global counter-terrorism and dealing with internal differences. The rise of Africa itself was not enough to attract attention. The European Union's European and African summits in Africa and the Tokyo International Conference on African Development in Japan and Africa have long existed, although both are not active enough. After the Beijing Summit, the development environment of China-Africa relations has changed dramatically, and the international cooperation mechanism towards Africa has flourished. After the Beijing Summit of the China-Africa Forum in 2006, many countries that have not yet established a comprehensive cooperation mechanism with Africa have held summits with Africa, the most important of which are South Korea, India and Turkey.

Although the international boom in non-cooperative mechanisms has constituted indirect competitive pressure on the development of China-Africa relations, the various improper criticisms of the international community dominated by Europe and the United States have created direct pressures and challenges for the development of China-Africa relations. This kind of pressure and challenge is mainly reflected in three aspects: First, the nickname "China model" is 
actually engaged in "new colonialism" in Africa. This argument is based on the continued rapid growth of Africa's total foreign trade. China-Africa trade has surpassed Europe's total trade with Africa, which has caused strong unease in the United States and Europe. The second is to advocate many other models to compete with the "Chinese model", especially the so-called "Indian model." On June 9, 2011, US Assistant Secretary of State Robert Black, who is in charge of South Asian and Central Asian affairs, said that the "Indian model encourages Africa's growth is impressive" when it talks about the second India-Africa summit. In addition, both Japan and South Korea have tried to export their "models" to Africa. Finally, some people stressed that the particularity of the Chinese model is difficult to adapt to Africa, and pointed out that Africa needs to build its own development model. China is replicating China's development by building similar special economic cooperation zones in Africa, but there are certain risks in transplanting the Chinese model.

\subsection{Sino-African Industrialization Cooperation and Other Cooperation Have Not Been Coordinated}

China-Africa industrialization cooperation will help promote the development of China-Africa economic and trade relations and support Chinese-funded enterprises to open up markets in Africa. It is also the core task of the Chinese government to transfer Chancheng. However, China's development of African markets is too concentrated, mainly in infrastructure, energy mining, etc., ignoring the coordinated development of other relevant key areas. The reasons for the backwardness of industrialization in Africa involve many aspects. Helping Africa accelerate its industrialization process will not only help Africa improve its backward infrastructure such as railways, highways, ports, electricity, water supply and information and communication, but also help Africa achieve a peaceful society and security. Environment, high-quality education and human resources reserves can increase the purchasing power of African people's consumer industrial products, reduce poverty and improve people's livelihood.

\subsection{Africa Is More Difficult to Withstand Large-Scale Capacity Transfer in China in the Short Term}

The capacity cooperation between China and Africa has theoretically mutual needs and complementary strategic significance. However, China's capacity cooperation with Africa has not yet unified Africa's cooperation as a whole. Although there are industrialization needs in African countries, the overall industrialization advantage of Africa is not obvious. The production capacity of many industrial products in China ranks first in the world. If the production capacity is transferred, most African countries cannot absorb a large amount of production capacity. China is still in the process of industrialization. The manufacturing industry has large but not strong problems in most industries. Although many industrial products are large in scale, their profitability is weak. Countries with a certain level of industrial development in Africa, such as South 
Africa and Nigeria, may be in the protection of their industries, resisting the transfer of low-end production capacity in China.

\section{Opportunities and Countermeasures for Capacity Cooperation in China and Africa}

\subsection{Consolidating the Foundation of Sustainable Development of China-Africa Relations}

China must adhere to the existing advantages of China-Africa relations and further consolidate the foundation for the sustainable development of China-Africa relations. It mainly includes three aspects. First of all, the China-Africa Cooperation Forum has become the core platform for China-Africa relations. In the face of improper criticism from Western society, China should strengthen its public diplomacy on China-Africa relations, especially the China-Africa Cooperation Forum. To implement a public diplomacy strategy, it is necessary to reasonably summarize and publicize the successful experiences and international contributions of China-Africa relations, avoid Western evaluation of inappropriate criticism of China-Africa relations, and become the discourse system that dominates China-Africa relations; foster China's own or understand China's non-Government organizations and civil society groups respond to and apply international "soft rules"; improve non-public foreign policy systems from institutional mechanisms; strengthen non-academic research and exchanges, especially international contributions to China-Africa relations, international comparison of African policies, etc. Discussion and exchanges.

\subsection{Infrastructure to Help Economic and Trade Development}

China is in a critical period of transformation and upgrading. The economic growth of African countries will help China achieve a smooth transfer of labor-intensive industries. Building industrial parks in Africa can enable more African people to find jobs. The "Belt and Road" provides new opportunities for Chinese companies to build infrastructure in Africa while also providing services for modern service companies in China. More financial institutions provide one-stop financial services for contracting enterprises, helping to ensure that enterprises can successfully realize the commercial operation of the project through reasonable arrangement of business and funds. Computer and communication enterprises provide intelligent platform services for real-time business operations, real-time monitoring and digital management operations and maintenance, and improve product quality and brand awareness of Chinese enterprises.

\subsection{Jointly Improving the Development of the Service Industry}

One of the most famous laws in development economics is that there is a positive correlation between the output of services and the proportion of per capita income. The rapid growth of the service industry has two acceleration periods: 
the first acceleration period is in countries with relatively low per capita annual income, that is, reaching 1800 US dollars per person, mainly composed of traditional service industries, such as accommodation, catering, cleaning, and beauty. Haircuts, etc. The second accelerator is in countries with high per capita GDP, and traditional services are increasingly being supplemented by modern banking, insurance, computer, communications and business services. When the per capita annual income reaches 4000 US dollars per person, the proportion of modern service industry will increase rapidly, and then the relationship between the service industry's share of GDP and per capita income will remain basically unchanged. Most countries in Africa are in the development stage of the traditional service industry, and China is increasing its support for the development of modern service industry. The infrastructure construction of African countries replicates the success factors of China's economic development. Pulling the GDP of African countries can increase the income of local people, drive the import and export of goods, and indirectly stimulate the growth of traditional service industries.

\subsection{Building Chinese Business Cards and Enhancing Corporate Brands}

The rapid growth of China's economy is China's gradual integration into the world's trading system, which involves trade, investment and technology dissemination within global trade rules. Especially after China joined the World Trade Organization, it has brought many ideal opportunities for China. The highways, bridges, high-speed rail, ships and other industries have developed at a high speed, and gradually created a "Chinese business card." At the same time, China's huge consumer market has nurtured a variety of domestic-funded enterprises, which have initially accumulated in the country and gradually matured within the trade rules. When the domestic market reaches a certain saturation state, domestic-funded enterprises need to go out and explore the international market, while enhancing their brand value and increasing the added value of products. The stability of the world trading system has created a powerful global development environment for China's trade, investment and technology communication. It has brought many ideal opportunities for the construction of China's Belt and Road, enabling them to use their own processes and technologies to catch up in world trade. International brand. At the same time, we will focus on scientific and technological talents to develop high-end manufacturing, increase research and development efforts, enhance brand technology, and re-industrialize through new fields such as new energy, new materials, artificial intelligence, and 5G, and strive to enter the first echelon under the geese mode.

\section{China-Africa Capacity Cooperation Model}

\subsection{Construction of Industrial Parks to Undertake Labor-Intensive Industry Transfer}

The sharp rise in labor costs has become the number one challenge for many la- 
bor-intensive manufacturing companies in China, and most African countries have become more prominent in terms of labor factors than China's rising labor costs, lower cost advantages and age structure advantages.

From the perspective of labor prices, China's average wage in 2018 has exceeded 6000 yuan, while Ethiopia's per capita cost is less than 80 dollars. In terms of the quantity of labor, sub-Saharan African countries have a population of about 900 million, and the dependency ratio of the old population is stable at around $6 \%$. The World Bank predicts that it will only grow to around $8 \%$ by 2050, while China started in 2013, the elderly population. The dependency ratio is growing rapidly and the World Bank expects to grow to $25 \%$ by 2030 . Compared to China, Africa is a young society and this advantage will remain for a long time.

Therefore, the construction of industrial parks in countries with relatively backward economies in Africa can attract a large number of labor-intensive enterprises to invest and build factories. The host government can obtain rich tax revenues from industrial parks and create a large number of jobs, while continuously improving the country's industrial structure.

\subsection{African Countries Upgrade Infrastructure through China-Africa Industrial Park}

The bottleneck for African countries to play a comparative advantage in China's industrial transfer is the lack of comprehensive infrastructure. In the case of insufficient state capital, priority can be given to the development of supporting facilities for production enterprises in industrial parks. Stable water, electricity and other supporting facilities can attract more enterprises to settle in industrial parks. Then, through the advantageous industries in the park, the state's fiscal revenue will be increased. With the accumulation of the state's fiscal revenue, the overall infrastructure level of the country will be gradually improved. Therefore, China-Africa capacity cooperation is not only a means of cooperation in the transfer of production capacity to Africa, but also a rare opportunity for African countries to improve their infrastructure.

\section{Conclusion: Exploring New Thinking}

For a long time, most countries in Africa have continued to accept donations from Western countries, but these countries are still in poverty. China and Africa maintain a partnership in the diplomatic and political fields. International capacity cooperation can tap a broader and deeper space for cooperation, explore symbiosis and win-win in the economic field, help African countries to fundamentally get rid of poverty, achieve stable economic growth, and enrich people's lives. The governments of both sides should play a guiding role in the top-level design, promote the facilitation of China-Africa capacity cooperation in various fields and realize the blueprint for building a community of human destiny. 


\section{Conflicts of Interest}

The author declares no conflicts of interest regarding the publication of this paper.

\section{References}

[1] Ozawa, T. (2005) Institutions, Industrial Upgrading, and Economic Performance in Japan. New Horizons in International Business, 22-23. https://doi.org/10.4337/9781845425678

[2] Eichengreen, B., Park, D. and Shin, K. (2011) When Fast Growing Economies Slow Down: International Evidence and Implications for the People's Republic of China. ADB Economics Working Paper Series, No. 262, 37. https://doi.org/10.2139/ssrn.1883962

[3] Pritchett, L. (2000) Understanding Patterns of Economic Growth: Searching for Hills among Plateaus, Mountains and Plains. World Bank Economic Review, 14, 221-250. https://doi.org/10.1093/wber/14.2.221

[4] Ben-David, D. and Papell, D. (1998) Slowdowns and Meltdowns: Postwar Growth Evidence from 74 Countries. Review of Economics and Statistics, 80, 561-571. https://doi.org/10.1162/003465398557834

[5] Lin, Y.F. and Tan, G.F. (1999) Policy Burdens, Accountability, and the Soft Budget Constraint. The American Economic Review, 89, 426-431. https://doi.org/10.1257/aer.89.2.426

[6] Zhao, Y.X., Wu, H.Y. and Li, H.M. (2018) The Mechanism and Practice of China-Africa Capacity Cooperation under the "Belt and Road Initiative": Based on the Perspective of New Structural Economics. International Trade, No. 4, 46.

[7] Xu, Z.S. (2018) Research on the Countermeasures of Industrial Structure Adjustment in Jilin Province in the New Period. Changbai Academic Journal, No.6, 107.

[8] He, C. and Liu, L.H. (2016) The Effect of Western Development Policy from the Perspective of Regional Coordinated Development Examine. Exploring Economic Issues, No. 7, 77.

[9] Zhang, C. (2012) China-Africa Relations: Addressing the Pressures and Challenges of International Cooperation in Africa. Diplomatic Review, No. 3, 36.

[10] Ogier, T. (2011) OECD Attacks China-Africa Trade "Myths". Emerging Markets.

[11] Eichengreen, B. and Gupta, P. (2011) The Two Waves of Service-Sector Growth. Oxford Economic Papers, 65, 96-123. https://doi.org/10.1093/oep/gpr059 